Technological University Dublin ARROW@TU Dublin

\title{
The Relationship Between Financial Distress and Well-Being: Exploring the role of self-employment
}

Jenny Berrill

Trinity College Dublin

Damien Cassells

Technological University Dublin, damien.cassells@tudublin.ie

Martha O'Hagan-Luff

Trinity College Dublin

See next page for additional authors

Follow this and additional works at: https://arrow.tudublin.ie/buschacart

Part of the Business Commons

\section{Recommended Citation}

Berrill, J., Cassells, D. \& O'Hagan-Luff. (2020). The Relationship Between Financial Distress and WellBeing: Exploring the role of self-employment. International Small Business Journal, vol. 39, no. 8, 026624262096538 . doi:10.1177/0266242620965384.

This Article is brought to you for free and open access by the School of Accounting and Finance at ARROW@TU Dublin. It has been accepted for inclusion in Articles by an authorized administrator of ARROW@TU Dublin. For more information, please contact arrow.admin@tudublin.ie, aisling.coyne@tudublin.ie, gerard.connolly@tudublin.ie. 


\section{Authors}

Jenny Berrill, Damien Cassells, Martha O'Hagan-Luff, and André van Stel

This article is available at ARROW@TU Dublin: https://arrow.tudublin.ie/buschacart/57 
See discussions, stats, and author profiles for this publication at: https://www.researchgate.net/publication/347251907

The relationship between financial distress and well-being: Exploring the role of self-employment

Article in International Small Business Journal · November 2020

DOI: $10.1177 / 0266242620965384$

CITATION

1

4 authors, including:

\section{Jenny Berrill}

Trinity College Dublin

17 PUBLICATIONS 157 CITATIONS

SEE PROFILE

Martha Carol O'Hagan-Luff

Trinity College Dublin

13 PUBLICATIONS 75 CITATIONS

SEE PROFILE
352

Damien Cassells

Technological University Dublin - City Campus

11 PUBLICATIONS 38 CITATIONS

SEE PROFILE 


\title{
The relationship between financial distress and well-being: Exploring the role of self-employment
}

International Small Business Journal: Researching Entrepreneurship

(C) The Author(s) 2020

Article reuse guidelines: sagepub.com/journals-permissions DOI: I0.I I77/0266242620965384 journals.sagepub.com/home/isb

(\$SAGE

\section{Jenny Berrill}

Trinity College Dublin, Ireland

\section{Damien Cassells}

Technological University Dublin, Ireland

\section{Martha O'Hagan-Luff}

Trinity College Dublin, Ireland

\section{André van Stel}

Trinity College Dublin, Ireland

Kozminski University, Poland

\begin{abstract}
This article will investigate the relationship between financial distress, well-being and employment status. Using several indicators of financial distress and of well-being, our econometric analysis shows that the negative association between financial distress and well-being is moderated by employment status in the sense that financial problems are more strongly associated with poor well-being for the self-employed compared to the wage-employed. Hence, when self-employed workers find themselves in a situation of financial distress, the negative consequences for their well-being are more severe. This is found to hold both for the self-employed with and without employees.
\end{abstract}

\section{Keywords}

financial distress, income, self-employment, wage-employed, well-being

\section{Introduction}

Financial distress is known to have a potentially devastating impact on well-being (Leana and Meuris, 2015). However, little is known about how this relationship may differ between 
wage-employed and self-employed workers (Wiklund et al., 2019). In this article, we compare the relationship between financial distress and well-being for these two types of workers; we find that financial problems are more strongly associated with lower levels of well-being for the selfemployed. Our findings have particular relevance during periods of crisis (Van Hal, 2015) given that financial problems, a common concern during such times, have different well-being consequences for wage-employed and self-employed workers. While it has been shown that, on average, self-employment has lower returns than wage-employment (Yuen et al., 2018), contemporary research shows that this is particularly evident for the self-employed without employees. Those with employees generally earn more than the wage-employed (Sorgner et al., 2017). Such evidence is important in the context of debated upon precarious employment, generally understood to be workers with low incomes, low social security and high job insecurity (Benach et al., 2014). Precarious workers, who can be found among both the wage-employed and the self-employed, are important from a policy perspective as they are at risk of falling into unemployment and inactivity with a higher risk of ill-health (Julià et al., 2017).

The self-employed are a heterogeneous category (Boegenhold and Fachinger, 2012; CRSE, 2017), ranging from highly successful and productive freelancers (Burke, 2011) to vulnerable workers being exploited by former employers (Román et al., 2011). Indeed, self-employment is a highly segmented occupational category with differing degrees of success, well-being and stress levels (Cieslik and Dvoulety, 2019). Notwithstanding this heterogeneity, it has been found that precariousness is a greater problem among the self-employed and particularly, the solo selfemployed, than among the wage-employed (Boegenhold and Klinglmair, 2015; Fachinger and Frankus, 2017). However, what is less clear is whether the well-being consequences of precariousness, in particular that of financial distress, differ among the wage-employed and self-employed. Stress related to financial distress has been shown to negatively affect well-being (Lewis et al., 2017; Zou et al., 2016); thus, not unsurprisingly, higher earnings reduce levels of depression and anxiety (Linder et al., 2020). Wiklund et al. (2019) suggest that the relationship between financial distress and well-being may differ for the self-employed and the wage-employed but note that evidence on this topic is scant and in the initial stages of investigation.

Therefore, this article investigates whether the relationship between financial distress and wellbeing differs between wage-workers and self-employed workers and within the latter group, between solo self-employed and employer entrepreneurs. This question is investigated using the Survey of Health, Ageing and Retirement in Europe (SHARE) database, a European dataset of wage-employed and self-employed workers aged 50 and over. This group is of relevance as numbers are increasing across Europe (Loretto and Vickerstaff, 2015). Using variables from this dataset, we specify and estimate a set of models relating four measures of well-being to employment status, two measures of financial distress and a wide range of control variables. Given that the evidence in the literature thus far is largely anecdotal in nature, we take an exploratory approach to our analysis using various measures of well-being and of financial distress, and see whether we can identify common patterns.

The analysis contributes to the extant literature in several ways. First and foremost, we provide systematic, large-scale econometric evidence on the relationship between financial distress and well-being and how this relationship may differ between different types of wageand self-employment. Second, four measures of well-being are used - overall health, mental health, life satisfaction and quality of life - in order to provide a more holistic analysis of well-being (Binder, 2018). Third, we employ a broader and thereby more appropriate measure of financial health than the usual measure of current income. Fourth, a broad range of control variables are used, including measures of job control and job demand which have been found to be vital for explaining work-related stress, subjective well-being, physical and mental health (Hessels et al., 2017; Wheatley, 2017). 
This article is organised as follows. The first section provides a literature review on the relationship between self-employment, financial health and well-being. Data, methods and results are then presented. Finally, discussion of our results and conclusions from the analysis are presented.

\section{Literature review and hypothesis development}

\section{Self-employment and financial health}

Although the decision to become self-employed is often motivated by more than monetary factors (Nicolaou et al., 2019; Wach et al., 2016), there is a strong focus upon the relationship between self-employment and financial health given its central importance. Sorgner et al. (2017) find that the self-employed with employees earn more than wage-earners, while the solo self-employed earn significantly less, highlighting the need to differentiate between these two categories of self-employed workers. Others report that satisfaction with income is lower for solo self-employed workers compared to both wage-workers and employer entrepreneurs (Van Der Zwan and Hessels, 2019). Entrepreneurship can lead to greater income inequality (Halvarsson et al., 2018); such income uncertainty increases precautionary savings above optimal levels (Broadway and Haisken-DeNew, 2019). We argue that greater income uncertainty may increase the likelihood of financial distress. Mwaura and Carter (2015) argue that income is a poor measure of the financial rewards of entrepreneurship, due to under-reporting, mismeasurement and its failure to fully capture the economic well-being of the entrepreneur. They focus instead on the stock of economic resources and find that entrepreneurial households are wealthier, but that the solo self-employed have lower levels of wealth than those with employees. Conversely, Yuen et al. (2018) show that employees earn more than the self-employed, while the financial wealth of both groups tend to be similar. Considering this evidence, we investigate whether the extent of financial distress is higher among the self-employed than among wage-workers, and within the category of self-employment, whether the extent of financial distress is higher among the solo self-employed than among the self-employed with employees.

\section{Financial health and well-being}

Preston (1975) states that there is a positive and concave relationship between income and health, and this is supported more recently by Carrieri and Jones (2017). Regarding the effect of income on social well-being, Ferrer-i-Carbonell (2005) finds that the relationship is generally positive but diminishing. Similarly, Lamu and Olsen (2016) find that the relative importance of income for subjective well-being is more important at the lower end of the distribution. Aittomäki et al. (2010) argue that current income is an insufficient measure of economic welfare, and find a strong positive association between wealth and health, while Schwandt (2018) finds a positive effect of wealth on physical health, mental health and survival rates. Wealth is also associated with a lower prevalence of poor self-rated health and clinical conditions in excess of the effect of income (Perel et al., 2006) while high levels of debt negatively affect health (Clayton et al., 2015; Selenko and Batinic, 2011). High debt repayments act as a source of anxiety leading to psychological distress and poor mental and physical health, which in turn may worsen financial welfare (Keese and Schmitz, 2014; Matthews and Gallo, 2011). Annink et al. (2016) find a strong negative relationship between financial hardship, measured by the individual's feeling about their income and access to borrowing, and subjective well-being. There are also noted associations between household wealth and psychological distress (Carter et al., 2009). 


\section{Financial health and well-being: the role of self-employment}

The relationship between financial health and well-being may differ for the self-employed and the wage-employed (Andersén, 2017; Wiklund et al., 2019). We argue that a threat to an individual's financial status can have a greater impact on health and well-being for the self-employed, due to the more far-reaching consequences of financial distress. In particular, in the case of debts or other financial distress, many of the self-employed are immediately at risk of losing their business and source of income. In addition, they risk losing their property, frequently used as collateral to finance the business (Schmalz et al., 2017). The emotional attachment to the firm is also stronger for the self-employed compared to the attachment of the wage-employed to a job (Hatak and Snellman, 2017; Shepherd, 2003). Hence, since the negative consequences of financial distress may be more acute and longer lasting in nature for the self-employed, their well-being will be more affected. This may be greater still for the self-employed with employees, as their businesses are typically bigger, and hence, the financial risks are greater.

Attraction-Selection-Attrition Theory, however, argues that entrepreneurs have a high capacity to manage stress, and as a result, entrepreneurs experience lower levels of stress (Baron et al., 2016). It has been noted that the self-employed are more satisfied with their jobs compared to similar employed persons (Nikolova, 2019) arising from greater flexibility and autonomy (Benz and Frey, 2008). The Job Demand-Control Model posits that control reduces the impact of job demands on strain and can help enhance employee job satisfaction (Karasek, 1979; Theorell and Karasek, 1996); indeed, Nikolova (2019) uses this model to show that switching to self-employment can be beneficial for health and well-being given greater job control. As employees may have less control over their work, they may feel a greater sense of uncertainty and distress when faced with financial difficulty (Ariza-Montes et al., 2018; Wood et al., 2020) but may have easier and better access to unemployment benefits reducing uncertainty during times of financial distress (Hessels et al., 2006).

The self-employed however, have greater responsibility for the outcome of their work than the wage-employed and hence, may feel greater shame when financial problems occur (Coad, 2014; Ucbasaran et al., 2013). Corner et al. (2017) explore entrepreneurs' emotional and psychological functioning after business failure noting high levels of resilience; nevertheless, Shepherd (2003) finds that business failure can result in emotional responses similar to grief. Financial difficulties may therefore, have an exaggerated effect on entrepreneur well-being more so than wage-workers, with less control over losing their employment. Moreover, D'Ambrosio et al. (2020) and Srivastava et al. (2001) find a negative relationship between the importance of money and subjective well-being. Srivastava et al. (2001) argue that money is of itself not driving the relationship but rather the motives behind wanting it, such as social positioning, a feeling of power, pride, status and overcoming self-doubt; the more importance people placed on money, the poorer their subjective well-being. These motives may be stronger for the self-employed, especially those who see entrepreneurship as a challenge (Tremblay and Genin, 2008).

Reviewing the literature leads us to create the following hypotheses to investigate whether the relationship between financial distress and well-being differs by employment status:

Hypothesis 1a: The negative relationship between financial distress and well-being is more pronounced for the self-employed than for the full-time wage-employed.

Hypothesis 1b: The negative relationship between financial distress and well-being is more pronounced for the self-employed with employees than for the solo self-employed. 


\section{Data and sample}

Following previous studies including Buffel et al. (2017), this analysis uses data from the SHARE (Boersch-Supan, 2017; Boersch-Supan et al., 2013). The SHARE project conducted over 297,000 interviews with 123,000 individuals aged 50 or older and their spouses, across 20 European countries and Israel, in six waves in 2005, 2007, 2009, 2011, 2013 and 2015, collecting data on health, employment, socio-economic status, social networks and other demographic factors. In total, 21 countries participated in the survey although not all countries participated in all waves. ${ }^{1}$ A similar dataset exists in the United States, the Health and Retirement Study, and in the United Kingdom, the English Longitudinal Study of Ageing, but the SHARE database is unique as a multi-country study. The dataset allows us to differentiate between those in full-time employment and selfemployment, and within self-employment between those with and without employees. We define full-time employment as those working 30 hours or more per week.

Data from Waves 2, 4, 5 and 6 are included. Many key variables are missing in Wave 1, and Wave 3 is excluded as it focuses on respondent life histories, with different survey questions than the other five waves. Only those aged 65 or under are included in order to capture the working age population, as the normal retirement age in the countries surveyed is 65 . Those identified as currently employed or self-employed are included, and those categorised as retired, sick, unemployed or homemaker are excluded. Restricting the dataset by these criteria reduces the sample size to between roughly 40,000 and 55,000 per variable as shown in Table 2 . These restrictions, by their nature, render the dataset cross-sectional in nature. The final sample sizes for our regression models are approximately 23,000 for Poor Overall Health, Life Satisfaction and Quality of Life, and about 19,000 for Depression.

\section{Model variables}

For our dependent variables, four measures of well-being are used: overall health, labelled Poor Overall Health; mental health, labelled Depression; and two further measures of well-being, Life Satisfaction and Quality of Life. Life Satisfaction measures a respondent's current feeling of happiness, whereas Quality of Life measures retrospective happiness. The exact variable definitions are provided in Table 1. These four measures encompass one objective measure, Poor Overall Health, and three subjective measures of well-being (Binder, 2018; Van Praag et al., 2003). Binder (2018) and Lowe (2018) both emphasise the importance of analysing both objective and subjective perspectives for a more holistic view of well-being.

The main independent variables measure a respondent's financial health; the most common indicator of financial health is current income. However, current income is only part of financial health and accumulated savings may be equally, if not more, important for well-being (Aittomäki et al., 2010; Mwaura and Carter, 2015). The impact of low income on well-being is likely to be stronger if there are no alternative resources available to meet financial responsibilities. Savings, and hence financial health, varies considerably and particularly among the self-employed (Fachinger and Frankus, 2017). Hence, we use a broader measure of financial health that considers a person's complete financial situation, an approach that is consistent with the OECD's analysis of income and wealth on well-being (OECD, 2013). Respondents to the survey were asked whether they had money worries and debts, apart from mortgage; these are labelled as indicators of financial distress. Stephan (2018) notes that it is often the subjective perceived sense of financial distress, typically related to perceived business failing, rather than the objective financial conditions that negatively affect the well-being of the self-employed. The use of a subjective measure, Money Worries, and an objective one, Debt, allows us to provide a more complete 


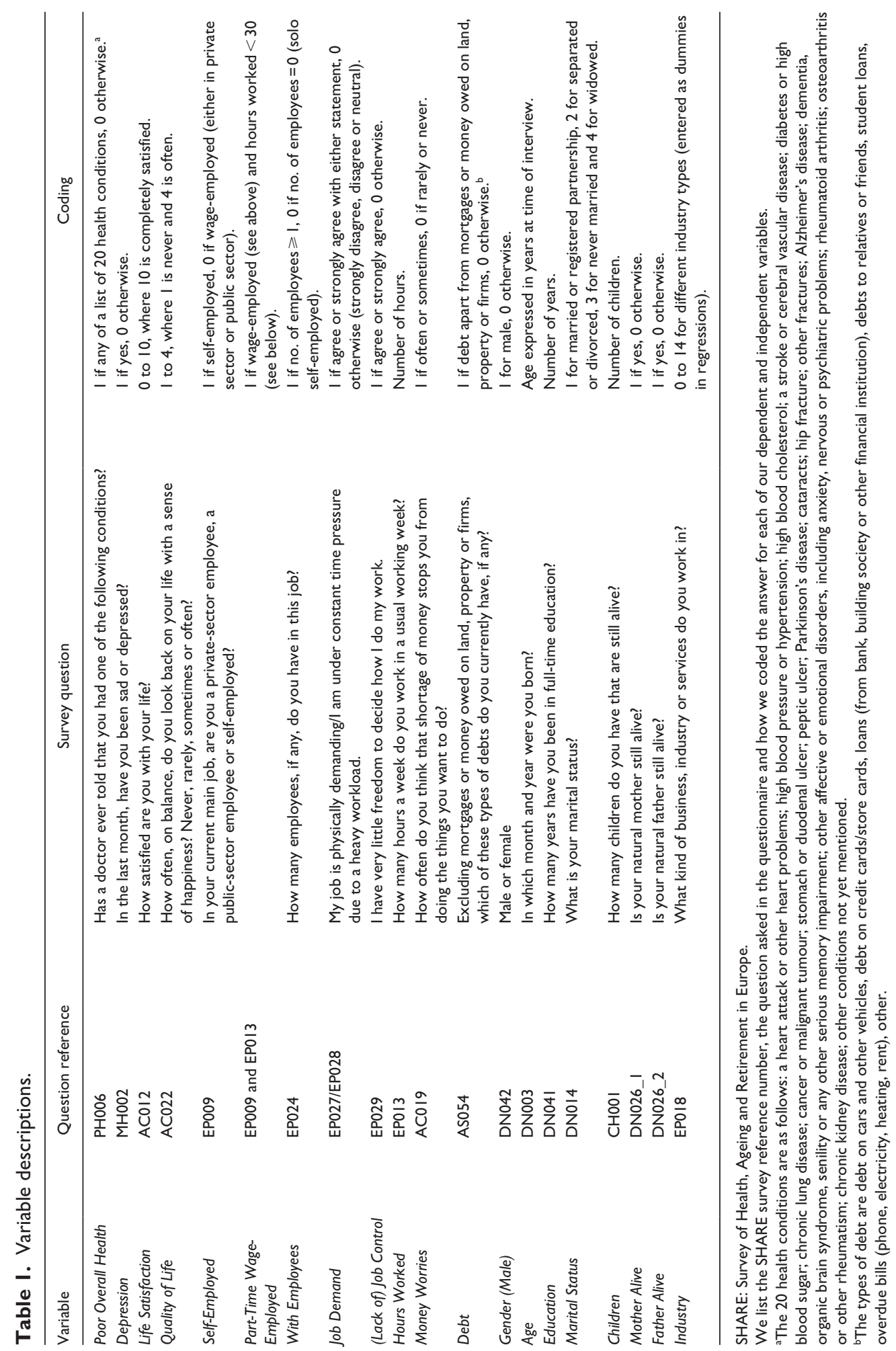


picture of financial distress. We refer to Table 1 for exact definitions. An additional advantage of using a measure broader than income is that the latter are often difficult to compare across countries and between the employed and the self-employed (Tedds, 2008).

Characteristics of the respondent's employment, Job Demand and Job Control, are also included - see Table 1 for definitions. The analysis also includes the variable Part-Time WageEmployed, a dummy indicating wage-workers working less than 30 hours per week. The part-time wage-employed are identified as a separate group from the full-time wage-employed as part-time work, if involuntary, is often associated with lower well-being (Kauhanen and Nätti, 2015). Moreover, we also include Log Hours Worked; this variable not only accounts for heterogeneity in the number of hours worked within the group of wage-employed but also captures the number of hours worked by the self-employed. This acts as a more general indicator of working time. Finally, a broad range of demographic control variables are included, which may affect our measures of well-being: Gender, Age, Age-Squared, Years of Education, Marital Status, Number of Children, Mother Alive and Father Alive. The analysis also includes a set of industry dummies. Variable definitions and associated survey questions for all model variables, including control variables, are given in Table 1.

\section{Descriptive statistics}

Descriptive statistics are presented in Table 2. When comparing full-time wage-employed to selfemployed by means of a $t$-test, the mean values for the self-employed are significantly lower for Poor Overall Health and Depression and significantly higher for Life Satisfaction, indicating that the self-employed are healthier and more satisfied with their lives than the wage-employed. The difference for Quality of Life is not significant. Similarly, the self-employed with employees are found to be healthier and happier than those without employees.

The wage-employed have less demanding jobs than both types of self-employment, but have the least control over their jobs; they work fewer hours than employer entrepreneurs, but more than the solo self-employed.

Money Worries are slightly lower for the self-employed as a whole relative to the wageemployed (50.8\% vs. 51.9\%), but the solo self-employed have greater money worries $(57.2 \%)$ than the self-employed with employees $(43.6 \%)$ or wage-employed $(51.9 \%)$. There is no significant difference in debt held by the self-employed and wage-employed, but the share of individuals with debts is higher among the solo self-employed compared to employer entrepreneurs. These results suggest that the solo self-employed are the least financially sound and highlight the importance of distinguishing between self-employed workers with and without employees.

\section{Methods and results}

\section{Methods}

For each of the four dependent variables measuring different aspects of well-being, four regression models are presented (see Tables 3-6). Model 1 is the basic model variant, which focuses on the impact of self-employment versus wage-employment, money worries and debt. Model 2 then introduces interaction terms between self-employment and the two measures of financial distress. This allows us to establish whether the relationship between financial distress and the well-being measures differs between self-employed and full-time wage-employed workers as per Hypothesis 1a. Model 3 then distinguishes between self-employed with and without employees, while Model 4 does the same but also includes interaction terms between the two types of self-employment, 


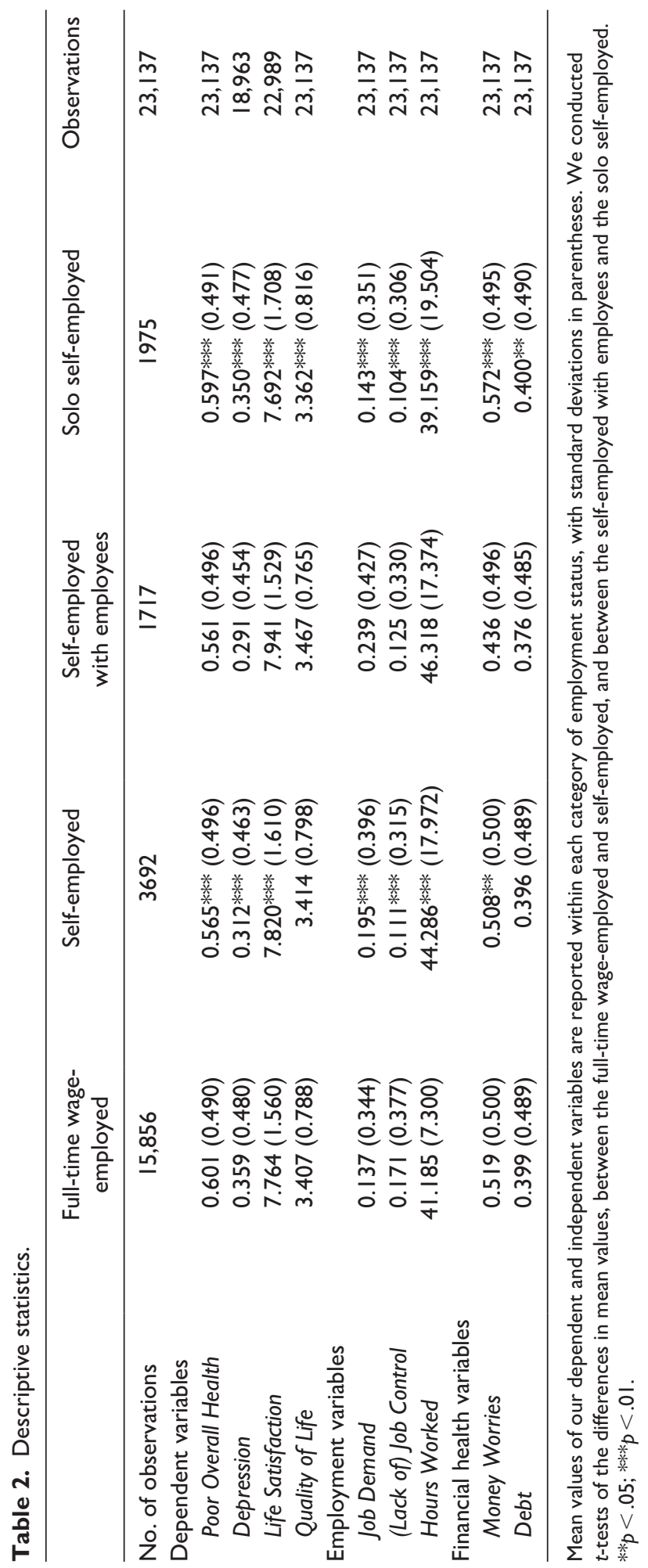


Solo versus With employees, and the two measures of financial distress. This model allows us to test Hypothesis $1 \mathrm{~b}$. Control variables as well as sets of country and industry dummies are included in each regression, and standard errors are clustered at the country level.

The analysis estimates pooled binary logit regressions for the dependent variables Poor Overall Health and Depression, and ordered logit regressions for Life Satisfaction and Quality of Life, as these latter variables can take on values other than 1 or 0 , while obeying a logical ordering. For all models, marginal effects and standard errors are reported. For Poor Overall Health and Depression, the marginal effects indicate changes in probability of suffering from those conditions, while for the other two variables, the marginal effects are to be interpreted in terms of making steps on a 10-point scale for Life Satisfaction or on a 4-point scale for Quality of Life. For the first two models, a positive marginal effect indicates a negative relationship with overall or mental health. For the final two models, a positive marginal effect indicates a positive relationship with Life Satisfaction or Quality of Life. The results are presented in Tables 3 to 6.

\section{Results}

In Table 3, the results for Poor Overall Health are reported. Relative to full-time wage-workers, being self-employed has a negative and significant relationship with this measure, indicating that the self-employed are less likely to report poor overall health (see Model 1). Concretely, our estimation result suggests that, compared to full-time wage-workers, the self-employed are 2.4 percentage points less likely to report poor overall health. Given the mean value of $60.1 \%$ reporting poor overall health among the full-time wage-employed in Table 2, this suggests a ceteris paribus reduction of $4.0 \%(=2.4 / 60.1)$ of the probability of poor overall health for the self-employed relative to the full-time wage-employed. When a distinction is made between the self-employed with and without employees, the solo self-employed are, ceteris paribus, 2.5 percentage points less likely to have poor health, compared to full-time wage-workers (see Model 3).

The coefficient for Job Demand is positive and significant, indicating a negative relationship with overall health. Those reporting a high level of job demand are over 3 percentage points more likely to have poor health. The coefficient for Log Hours Worked is negative and significant, indicating that those working longer hours are in better health. Although a significant relationship is found, the causation would likely run in the opposite direction; those in good health will tend to work longer hours or at least have the capacity to do so. The Part-Time Wage-Employed are about 4 percentage points more likely to have poor health, relative to full-time wage-employed, making this group the most vulnerable in terms of poor health, given that the self-employed also report better overall health.

Money Worries and Debt have a strongly significant and positive relationship with Poor Overall Health, as expected. Both these circumstances are associated with a higher probability of poor health of roughly 6 percentage points. Looking at the interaction terms, being self-employed with money worries is associated with worse overall health (Model 2), and this holds in particular for the solo self-employed (Model 4). Thus, money worries are negatively related to overall health for all employment statuses, but this negative relation is even stronger for the solo self-employed, that is, this group of workers seems to suffer even more from money worries, in terms of the probability of having poor health. Indeed, the impact of money worries on the probability of poor health is found to be almost twice as high for the solo self-employed: while money worries increase the probability of poor health by 6.2 percentage points for the wage-employed, this increase is 11.8 percentage points $(6.2+5.6)$ for the solo self-employed.

Two interesting findings exist among the control variables. The first relates to the circumstance of being widowed, which is associated with a roughly 4 percentage points higher probability of 
Table 3. Pooled logit regression results for poor overall health.

\begin{tabular}{|c|c|c|c|c|}
\hline & Model (I) & Model (2) & Model (3) & Model (4) \\
\hline \multicolumn{5}{|l|}{ Employment variables } \\
\hline Self-Employed & $-0.024(0.012)^{* *}$ & $-0.037(0.02)^{*}$ & & \\
\hline Self-Employed With Employees & & & $-0.021(0.017)$ & $-0.034(0.027)$ \\
\hline Solo Self-Employed & & & $-0.025(0.012)^{* *}$ & $-0.045(0.021)^{* *}$ \\
\hline Job Demand & $0.032(0.01 \mathrm{I})^{* * * *}$ & $0.031(0.01 \mathrm{I})^{* * * *}$ & $0.032(0.011)^{* * *}$ & $0.032(0.011)^{* * * *}$ \\
\hline (Lack of) Job Control & $-0.001(0.006)$ & $-0.004(0.006)$ & $-0.001(0.005)$ & $0(0.006)$ \\
\hline Log Hours Worked & $-0.021(0.007)^{* * *}$ & $-0.02(0.008)^{* *}$ & $-0.021(0.007)^{* * *}$ & $-0.022(0.007)^{* * *}$ \\
\hline Part-Time Wage-Employed & $0.037(0.017)^{* *}$ & $0.043(0.023)^{*}$ & $0.037(0.016)^{* *}$ & $0.043(0.022)^{*}$ \\
\hline \multicolumn{5}{|l|}{ Financial health variables } \\
\hline Money Worries & $0.065(0.01 \mathrm{I})^{* * *}$ & $0.064(0.011)^{* * *}$ & $0.066(0.011)^{* * *}$ & $0.062(0.011)^{* * * *}$ \\
\hline Debt & $0.059(0.008)^{* * *}$ & $0.059(0.01)^{* * *}$ & $0.059(0.008)^{* * *}$ & $0.057(0.0 \mathrm{I})^{* * *}$ \\
\hline \multicolumn{5}{|l|}{ Interaction terms } \\
\hline Self-Employed $\times$ Money Worries & & $0.025(0.013)^{*}$ & & \\
\hline Self-Employed $\times$ Debt & & $-0.004(0.019)$ & & \\
\hline With Employees $\times$ Money Worries & & & & $-0.003(0.017)$ \\
\hline With Employees $\times$ Debt & & & & $-0.023(0.022)$ \\
\hline Solo $\times$ Money Worries & & & & $0.056(0.018)^{* * *}$ \\
\hline Solo $\times$ Debt & & & & $0.022(0.027)$ \\
\hline \multicolumn{5}{|l|}{ Demographic controls } \\
\hline Gender (Male) & $0.019(0.012)^{*}$ & $0.018(0.011)$ & $0.019(0.012)^{*}$ & $0.019(0.012)$ \\
\hline Age & $0.035(0.013)^{* * *}$ & $0.049(0.01)^{* * *}$ & $0.035(0.013)^{* * *}$ & $0.035(0.012)^{* * *}$ \\
\hline Age-Squared & $0.000(0.000)$ & $0.000(0.000)^{* * *}$ & $0.000(0.000)$ & $0.000(0.000)$ \\
\hline Education & $-0.003(0.002)^{*}$ & $-0.003(0.002)^{*}$ & $-0.003(0.002)^{*}$ & $-0.003(0.002)$ \\
\hline Divorced & $0.009(0.013)$ & $0.010(0.125)$ & $0.009(0.013)$ & $0.010(0.012)$ \\
\hline Never Married & $0.011(0.014)$ & $0.006(0.015)$ & $0.011(0.014)$ & $0.009(0.015)$ \\
\hline Widowed & $0.039(0.02)^{* *}$ & $0.036(0.022)^{*}$ & $0.039(0.019)^{* *}$ & $0.037(0.02)^{*}$ \\
\hline Children & $-0.006(0.004)$ & $-0.007(0.004)^{* *}$ & $-0.006(0.004)$ & $-0.006(0.004)^{*}$ \\
\hline Mother Alive & $-0.03(0.008) * * *$ & $-0.03(0.008)^{* * *}$ & $-0.03(0.008)^{* * *}$ & $-0.03(0.008)^{* * *}$ \\
\hline Father Alive & $-0.026(0.013)^{* *}$ & $-0.027(0.013)^{* *}$ & $-0.026(0.013)^{* *}$ & $-0.026(0.013)^{* *}$ \\
\hline Country dummies & YES & YES & YES & YES \\
\hline Wave dummies & YES & YES & YES & YES \\
\hline Industry dummies & YES & YES & YES & YES \\
\hline No. of observations & 23,137 & 23,137 & 23,137 & 23,137 \\
\hline Pseudo- $R^{2}$ & .0354 & .0396 & .0354 & .0356 \\
\hline
\end{tabular}

We list the results for four models using the same dependent variable, Poor Overall Health. The first and second models have Self-Employed as the main independent variable, without and with interaction terms; the third and fourth have SelfEmployed With Employees and Solo Self-Employed as the main independent variables, without and with interaction terms. Marginal effects are reported. Standard errors are in parentheses and are clustered at the country level. $*_{p}<.10 ; * *_{p}<.05 ; * * p<.01$.

poor health; the second to the fact that one's father is still alive. As the sample consists of those 50 and over, this is not straightforward. The latter circumstance is associated with a 2.6 percentage points lower chance of having poor overall health.

Table 4 reports the results for our measure of mental health, Depression, while Tables 5 and 6 report the results for Life Satisfaction and Quality of Life. 
Table 4. Pooled logit regression results for depression.

\begin{tabular}{|c|c|c|c|c|}
\hline & Model (I) & Model (2) & Model (3) & Model (4) \\
\hline \multicolumn{5}{|l|}{ Employment variables } \\
\hline Self-Employed & $-0.001(0.013)$ & $-0.00 \mathrm{I}(0.024)$ & & \\
\hline Self-Employed With Employees & & & $0.005(0.018)$ & $-0.014(0.03)$ \\
\hline Solo Self-Employed & & & $-0.005(0.015)$ & $0.011(0.029)$ \\
\hline Job Demand & $0.05(0.01)^{* * *}$ & $0.049(0.01)^{* * *}$ & $0.049(0.01)^{* * *}$ & $0.049(0.01)^{* * *}$ \\
\hline (Lack of) Job Control & $0.025(0.01 \mathrm{I})^{* *}$ & $0.025(0.011)^{* *}$ & $0.025(0.01 \mathrm{I})^{* *}$ & $0.025(0.01 \mathrm{I})^{* *}$ \\
\hline Log Hours Worked & $-0.004(0.008)$ & $-0.004(0.008)$ & $-0.004(0.009)$ & $-0.004(0.009)$ \\
\hline Part-Time Wage-Employed & $0.035(0.014)^{* *}$ & $0.035(0.014)^{* *}$ & $0.035(0.014)^{* *}$ & $0.034(0.014)^{* *}$ \\
\hline \multicolumn{5}{|l|}{ Financial health variables } \\
\hline Money Worries & $0.098(0.009)^{* * * *}$ & $0.098(0.01)^{* * *}$ & $0.099(0.009)^{* * * *}$ & $0.098(0.01)^{* * *}$ \\
\hline Debt & $0.044(0.013)^{* * *}$ & $0.042(0.013)^{* * *}$ & $0.044(0.013)^{* * * *}$ & $0.048(0.014)^{* * * *}$ \\
\hline \multicolumn{5}{|l|}{ Interaction terms } \\
\hline Self-Employed $\times$ Money Worries & & $0.014(0.022)$ & & \\
\hline Self-Employed $\times$ Debt & & $0.001(0.025)$ & & \\
\hline With Employees $\times$ Money Worries & & & & $0.048(0.025)^{*}$ \\
\hline With Employees $\times$ Debt & & & & $-0.012(0.029)$ \\
\hline Solo $\times$ Money Worries & & & & $-0.016(0.025)$ \\
\hline Solo $\times$ Debt & & & & $0.012(0.038)$ \\
\hline \multicolumn{5}{|l|}{ Demographic controls } \\
\hline Gender (Male) & $-0.123(0.014)^{* * *}$ & $-0.122(0.014)^{* * * *}$ & $-0.123(0.014)^{* * *}$ & $-0.123(0.014)^{* * *}$ \\
\hline Age & $0.049(0.023)^{* *}$ & $0.049(0.023)^{* *}$ & $0.049(0.023) * *$ & $0.049(0.023)^{* *}$ \\
\hline Age-Squared & $-0.000(0.000)^{* *}$ & $-0.000(0.000)^{* *}$ & $-0.000(0.000)^{* *}$ & $-0.000(0.000)^{* *}$ \\
\hline Education & $0.003(0.002)^{*}$ & $0.003(0.002)^{*}$ & $0.003(0.002)^{*}$ & $-0.003(0.002)^{*}$ \\
\hline Divorced & $0.069(0.009)^{* * *}$ & $0.069(0.009)^{* * *}$ & $0.069(0.009) * * *$ & $0.069(0.009)^{* * *}$ \\
\hline Never Married & $0.038(0.015)^{* *}$ & $0.037(0.015)^{* *}$ & $0.038(0.015)^{* *}$ & $0.038(0.015)^{* *}$ \\
\hline Widowed & $0.139(0.029)^{* * *}$ & $0.139(0.029)^{* * *}$ & $0.139(0.029)^{* * *}$ & $0.139(0.029)^{* * *}$ \\
\hline Children & $0.003(0.004)$ & $0.003(0.004)$ & $0.003(0.004)$ & $0.003(0.004)$ \\
\hline Mother Alive & $-0.019(0.009)^{*}$ & $-0.019(0.009)^{*}$ & $-0.019(0.009)^{*}$ & $-0.019(0.009) *$ \\
\hline Father Alive & $0.010(0.011)$ & $0.010(0.011)$ & $0.010(0.011)$ & $-0.010(0.011)$ \\
\hline Country dummies & YES & YES & YES & YES \\
\hline Wave dummies & YES & YES & YES & YES \\
\hline Industry dummies & YES & YES & YES & YES \\
\hline No. of observations & 18,963 & 18,963 & 18,963 & 18,963 \\
\hline Pseudo- $R^{2}$ & .0621 & .0601 & .0615 & .0601 \\
\hline
\end{tabular}

We list the results for four models using the same dependent variable, Depression. The first and second models have Self-Employed as the main independent variable, without and with interaction terms; the third and fourth have SelfEmployed With Employees and Solo Self-Employed as the main independent variables, without and with interaction terms. Marginal effects are reported. Standard errors are in parentheses and are clustered at the country level. $*_{p}<.10 ; * * p<.05 ; * * * p<.01$.

An overview of the main regression results related to Hypotheses $1 \mathrm{a}$ and $1 \mathrm{~b}$ for the four measures of well-being is presented in Table 7. For each measure, the table indicates whether the employment status variables, the financial health variables and interaction terms are significant at the $10 \%$ level or below and if so whether the coefficient is positive or negative. Again, for Poor Overall Health and Depression variables, a positive sign indicates worse overall or mental health, whereas for Life Satisfaction and Quality of Life variables, a positive sign indicates greater well-being. 
Table 5. Ordered logit regression results for life satisfaction.

\begin{tabular}{|c|c|c|c|c|}
\hline & Model (I) & Model (2) & Model (3) & Model (4) \\
\hline \multicolumn{5}{|l|}{ Employment variables } \\
\hline Self-Employed & $0.008(0.004)^{* *}$ & $0.002(0.008)$ & & \\
\hline Self-Employed With Employees & & & $0.009(0.004)^{* *}$ & $0.006(0.009)$ \\
\hline Solo Self-Employed & & & $0.008(0.005)$ & $-0.002(0.012)$ \\
\hline Job Demand & $-0.022(0.004)^{* * *}$ & $-0.022(0.004)^{* * *}$ & $-0.022(0.004)^{* * *}$ & $-0.022(0.004)^{* * *}$ \\
\hline (Lack of) Job Control & $-0.02(0.004)^{* * *}$ & $-0.02(0.004)^{* * *}$ & $-0.02(0.004)^{* * *}$ & $-0.02(0.004)^{* * *}$ \\
\hline Log Hours Worked & $0.012(0.004)^{* * * *}$ & $0.012(0.004)^{* * *}$ & $0.012(0.004)^{* * * *}$ & $0.012(0.004)^{* * *}$ \\
\hline Part-Time Wage-Employed & $-0.003(0.004)$ & $0.003(0.007)$ & $-0.003(0.004)$ & $0.003(0.007)$ \\
\hline \multicolumn{5}{|l|}{ Financial health variables } \\
\hline Money Worries & $-0.092(0.008)^{* * *}$ & $-0.088(0.008)^{* * *}$ & $-0.092(0.008)^{* * *}$ & $-0.089(0.008)^{* * *}$ \\
\hline Debt & $-0.003(0.004)$ & $-0.001(0.004)$ & $-0.003(0.004)$ & $-0.00 \mathrm{I}(0.004)$ \\
\hline \multicolumn{5}{|l|}{ Interaction terms } \\
\hline Self-Employed $\times$ Money Worries & & $-0.007(0.009)$ & & \\
\hline Self-Employed $\times$ Debt & & $-0.018(0.01)^{*}$ & & \\
\hline With Employees $\times$ Money Worries & & & & $-0.004(0.007)$ \\
\hline With Employees $\times$ Debt & & & & $0.01(0.013)$ \\
\hline Solo $\times$ Money Worries & & & & $0.006(0.012)$ \\
\hline Solo $\times$ Debt & & & & $-0.029(0.013)^{* *}$ \\
\hline \multicolumn{5}{|l|}{ Demographic controls } \\
\hline Gender (Male) & $-0.005(0.004)$ & $-0.005(0.004)$ & $-0.005(0.004)$ & $-0.005(0.004)$ \\
\hline Age & $-0.018(0.005)^{* * *}$ & $-0.017(0.005)^{* * *}$ & $-0.018(0.005)^{* * *}$ & $-0.018(0.005)^{* * *}$ \\
\hline Age-Squared & $0.000(0.000)^{* * *}$ & $0.000(0.000)^{* * *}$ & $0.000(0.000)^{* * *}$ & $0.000(0.000)^{* * *}$ \\
\hline Education & $0.001(0.000)^{* * *}$ & $0.001(0.000)^{* * *}$ & $0.001(0.000) * * *$ & $0.001(0.000)^{* * *}$ \\
\hline Divorced & $-0.049(0.004)^{* * *}$ & $-0.049(0.004)^{* * *}$ & $-0.049(0.004)^{* * *}$ & $-0.049(0.004)^{* * *}$ \\
\hline Never Married & $-0.037(0.005) * * *$ & $-0.037(0.005)^{* * *}$ & $-0.037(0.005)^{* * * *}$ & $-0.037(0.005)^{* * *}$ \\
\hline Widowed & $-0.059(0.005) * * *$ & $-0.059(0.005)^{* * *}$ & $-0.059(0.005)^{* * *}$ & $-0.059(0.005)^{* * *}$ \\
\hline Children & $0.008(0.002)^{* * *}$ & $0.008(0.002)^{* * *}$ & $0.008(0.002)^{* * *}$ & $0.008(0.002)^{* * *}$ \\
\hline Mother Alive & $0.002(0.003)$ & $0.002(0.003)$ & $0.002(0.003)$ & $0.002(0.003)$ \\
\hline Father Alive & $0.004(0.004)$ & $0.004(0.004)$ & $0.004(0.004)$ & $0.004(0.004)$ \\
\hline Country dummies & YES & YES & YES & YES \\
\hline Wave dummies & YES & YES & YES & YES \\
\hline Industry dummies & YES & YES & YES & YES \\
\hline No. of observations & 22,985 & 22,985 & 22,985 & 22,985 \\
\hline Pseudo- $R^{2}$ & .0572 & .0573 & .0572 & .0573 \\
\hline
\end{tabular}

We list the results for four models using the same dependent variable, Life Satisfaction. The first and second models have Self-Employed as the main independent variable, without and with interaction terms; the third and fourth have SelfEmployed With Employees and Solo Self-Employed as the main independent variables, without and with interaction terms. Marginal effects are reported. Standard errors are in parentheses and are clustered at the country level. $*_{p}<.10 ; * * p<.05 ; * * *<<.01$.

The self-employed and in particular the solo self-employed are found to have better overall health than the full-time wage-employed. For Depression, there is little difference by employment type. For Life Satisfaction and Quality of Life, the self-employed and the self-employed with employees are happier than the wage-employed, but there is no significant difference between the solo self-employed and the reference category, full-time wage-employed. Having money worries is bad for overall health, mental health, life satisfaction and quality of life while 
Table 6. Ordered logit regression results for quality of life.

\begin{tabular}{|c|c|c|c|c|}
\hline & Model (I) & Model (2) & Model (3) & Model (4) \\
\hline \multicolumn{5}{|l|}{ Employment variables } \\
\hline Self-Employed & $0.016(0.008)^{* *}$ & $0.029(0.021)$ & & \\
\hline Self-Employed With Employees & & & $0.03(0.013)^{* *}$ & $0.058(0.028) * *$ \\
\hline Solo Self-Employed & & & $0.004(0.012)$ & $0.001(0.027)$ \\
\hline Job Demand & $-0.021(0.01)^{* *}$ & $-0.021(0.009)^{* *}$ & $-0.021(0.009)^{* *}$ & $-0.021(0.009)^{* *}$ \\
\hline (Lack of) Job Control & $-0.037(0.016)^{* *}$ & $-0.037(0.15)^{* *}$ & $-0.037(0.016)^{* *}$ & $-0.038(0.016)^{* *}$ \\
\hline Log Hours Worked & $0.016(0.008)^{* *}$ & $0.016(0.007)^{* *}$ & $0.014(0.008)^{*}$ & $0.014(0.008)^{* *}$ \\
\hline Part-Time Wage-Employed & $-0.025(0.014)^{*}$ & $-0.024(0.014)^{*}$ & $-0.026(0.014)^{*}$ & $-0.025(0.014)^{*}$ \\
\hline \multicolumn{5}{|l|}{ Financial health variables } \\
\hline Money Worries & $-0.114(0.012)^{* * *}$ & $-0.107(0.012)^{* * *}$ & $-0.113(0.012)^{* * *}$ & $-0.107(0.014)^{* * *}$ \\
\hline Debt & $-0.024(0.009)^{* *}$ & $-0.021(0.011)^{* *}$ & $-0.024(0.009)^{* *}$ & $-0.02 \mathrm{I}(0.01 \mathrm{I})^{* *}$ \\
\hline \multicolumn{5}{|l|}{ Interaction terms } \\
\hline Self-Employed $\times$ Money Worries & & $-0.04 \mid(0.021)^{* *}$ & & \\
\hline Self-Employed $\times$ Debt & & $-0.014(0.021)$ & & \\
\hline With Employees $\times$ Money Worries & & & & $-0.048(0.024)^{* *}$ \\
\hline With Employees $\times$ Debt & & & & $0.036(0.03)$ \\
\hline Solo $\times$ Money Worries & & & & $-0.028(0.028)$ \\
\hline Solo $\times$ Debt & & & & $-0.010(0.028)$ \\
\hline \multicolumn{5}{|l|}{ Demographic controls } \\
\hline Gender (Male) & $-0.021(0.013)$ & $-0.021(0.013)$ & $-0.021(0.013)$ & $-0.021(0.013)$ \\
\hline Age & $-0.007(0.014)$ & $-0.006(0.014)$ & $-0.006(0.014)$ & $-0.007(0.014)$ \\
\hline Age-Squared & $0.000(0.000)$ & $0.000(0.000)$ & $0.000(0.000)$ & $0.000(0.000)$ \\
\hline Education & $0.006(0.00 \mathrm{I})^{* * *}$ & $0.006(0.001)^{* * *}$ & $0.006(0.001)^{* * *}$ & $0.006(0.001)^{* * *}$ \\
\hline Divorced & $-0.154(0.018)^{* * *}$ & $-0.154(0.018)^{* * *}$ & $-0.153(0.018)^{* * *}$ & $-0.154(0.018)^{* * *}$ \\
\hline Never Married & $-0.116(0.015)^{* * *}$ & $-0.116(0.015)^{* * *}$ & $-0.116(0.015)^{* * * *}$ & $-0.116(0.015)^{* * *}$ \\
\hline Widowed & $-0.096(0.021)^{* * *}$ & $-0.095(0.021)^{* * *}$ & $-0.096(0.021)^{* * *}$ & $-0.095(0.021)^{* * *}$ \\
\hline Children & $0.016(0.004)^{* * *}$ & $0.016(0.004)^{* * *}$ & $0.016(0.004)^{* * *}$ & $0.016(0.004)^{* * *}$ \\
\hline Mother Alive & $0.007(0.009)$ & $0.007(0.009)$ & $0.007(0.009)$ & $0.007(0.009)$ \\
\hline Father Alive & $-0.007(0.009)$ & $-0.007(0.009)$ & $-0.007(0.009)$ & $-0.007(0.009)$ \\
\hline Country dummies & YES & YES & YES & YES \\
\hline Wave dummies & YES & YES & YES & YES \\
\hline Industry dummies & YES & YES & YES & YES \\
\hline No. of observations & 22,979 & 22,979 & 22,979 & 22,979 \\
\hline Pseudo- $R^{2}$ & .0496 & .0500 & .0496 & .0501 \\
\hline
\end{tabular}

We list the results for four models using the same dependent variable, Quality of Life. The first and second models have Self-Employed as the main independent variable, without and with interaction terms; the third and fourth have SelfEmployed With Employees and Solo Self-Employed as the main independent variables, without and with interaction terms. Marginal effects are reported. Standard errors are in parentheses and are clustered at the country level. $*_{p}<.10 ; * * p<.05 ; * * * p<.01$.

having debts is bad for three out of these four well-being measures, life satisfaction being the exception.

Regarding the interaction terms, being self-employed with money worries has a positive association with Poor Overall Health, in particular for the solo self-employed. Moreover, having money worries and being self-employed with employees have a positive association with Depression. Having debt or money worries while being self-employed is associated with lower 


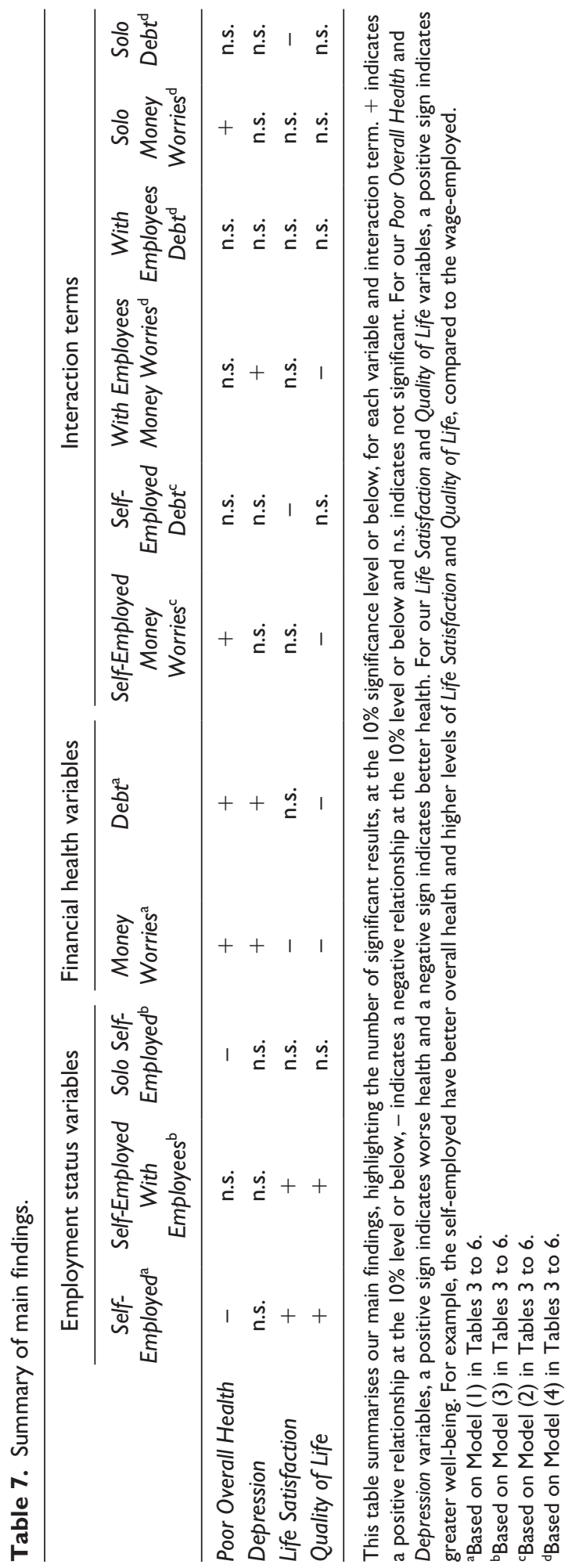


levels of Life Satisfaction and Quality of Life, while being solo self-employed with debt and having money worries with employees reduce the incidence of high scores for these variables.

Given the exploratory nature of our empirical analysis, we are not in the position to offer theoretical explanations for the difference in results for our measures of financial distress but we do note that, where significant, the coefficients were in the expected direction. On balance, findings support Hypothesis 1a, the negative impact of financial distress on well-being ${ }^{2}$ is exacerbated for the self-employed relative to the wage-employed. ${ }^{3}$ We further investigated whether the negative relationship between financial distress and well-being was more pronounced for the self-employed with employees than for the solo self-employed. Hypothesis $1 \mathrm{~b}$ is supported by the findings for Depression and Quality of Life in the sense that the interaction term for 'With Employees' is significant in the expected direction, and the interaction term for 'Solo' is not significant. ${ }^{4}$ In contrast, for Poor Overall Health and Life Satisfaction, estimation results suggest that the negative wellbeing effects of financial distress may be stronger for the solo self-employed. Overall, our results suggest that Hypothesis $1 \mathrm{~b}$ is not supported.

Finally, Tables 3 to 6 also show that a job that is demanding or over which a worker feels they have little control has a negative association with almost all of the dependent variables, while hours worked has a positive association. Age is generally negatively associated with all measures of well-being, but at a decreasing rate, while being married, having children, having more years of education and having parents alive are positively associated with well-being, where significant. Gender is only significant for Depression, with men reporting a 12 percentage points lower probability of suffering from depression (see Table 4). Two other remarkable findings from Table 4 are that money worries $(+10$ percentage points) and being widowed $(+14$ percentage points) are relatively strongly associated with the probability of suffering from depression.

\section{Discussion}

Binder (2018) outlines the importance of considering subjective well-being in policy creation for the self-employed suggesting that policies should focus not only on objective economic factors such as income and job creation but also on subjective factors. These include issues such as confidence, stress and worries, which also contribute to the overall well-being of the selfemployed. In addition to using such objective and subjective measures of well-being, we also use measures for financial distress finding that this construct and well-being are strongly linked. Our results suggest these links are even stronger for the self-employed. Hence, policies focusing on the self-employed should not only consider their economic situation but should do this in tandem with their broader well-being in terms of health and happiness (Binder, 2018). This issue is topical in light of the current COVID-19 pandemic crisis. Governments on a global scale face a trade-off between the direct health consequences for the population at large and economic damage (McKee and Stuckler, 2020). However, over time, there will not only be a trade-off between direct health damage, for example, the number of citizens infected by the virus and economic damage, but the second-order health consequences should also be taken into consideration. In particular, those who are not directly affected by the virus may still suffer serious health damage as a result of heavy financial distress arising from the measures taken to fight its spread, leading to the threat of unemployment or forced business closure. We help to inform these difficult decisions as it investigates whether the negative health consequences of financial distress differ between wage-workers and entrepreneurs.

A limitation of our work is that it is cross-sectional in nature. Given the exploratory nature of our analysis, contributing to the limited research in this area (Wiklund et al., 2019), we have 
established new statistical associations between employment status, well-being and financial health. To this end, we confirm self-employment is more precarious than wage-employment, in terms of the share of those within each employment status category who experience financial distress and also in terms of the well-being consequences of this distress. A future area of work would be to investigate this relationship over time exploring the long-term consequences of financial distress for the self-employed. Another avenue of research would be to analyse the impact of the social security measures provided during the current crisis on the perceived and actual financial distress experienced by the self-employed and the impact on well-being. Qualitative research may provide further insights in this regard. Findings from this study could be used to inform future policy on the social protection provided for self-employed workers. A final direction for future research would be to investigate whether and how hybrid self-employment - that is, self-employment as a secondary job next to a main job in wage-employment - relieves financial distress and the well-being consequences of financial distress (Boegenhold, 2019).

\section{Conclusion}

This article investigated whether the well-being consequences of financial distress differed between the wage-employed and self-employed, and within the latter group, between solo selfemployed and employer entrepreneurs. This question was tested by considering whether money worries or debt had more severe negative consequences for well-being for the self-employed than for the wage-employed. Results were not uniformly significant, but overall, they were consistently in the direction of self-employed workers suffering more severe negative well-being consequences from financial distress, compared to full-time wage-workers. In particular, financial distress had a greater negative association with overall health and life satisfaction for the solo self-employed compared to wage-workers, while the negative association with mental health and quality of life was found to be most pronounced for the self-employed with employees. These results should be of major importance for policy makers as we confirm earlier findings by Boegenhold and Klinglmair (2015) and Fachinger and Frankus (2017) showing that a greater share of self-employed may be considered precarious in terms of having money worries. This holds particularly for the solo self-employed.

\section{Funding}

The author(s) received no financial support for the research, authorship, and/or publication of this article.

\section{ORCID iDs}

Jenny Berrill (iD https://orcid.org/0000-0002-3098-8158

André van Stel (iD) https://orcid.org/0000-0003-4512-654X

\section{Notes}

1. Austria, Belgium, Switzerland, Germany, Denmark, Spain, France, Greece, Italy, Netherlands, Sweden and Israel participated from Wave 1 onwards; Czech Republic, Ireland and Poland joined in Wave 2; Estonia, Hungary, Portugal and Slovenia joined in Wave 4; Luxembourg in Wave 5 and Croatia in Wave 6.

2. That the general relationship between financial distress and well-being is negative was found in seven out of eight cases in the second panel of Table 7 (financial health variables), while the remaining case was not significant (i.e. the relationship between debt and life satisfaction). 
3. To be precise, Hypothesis 1a is confirmed for three out of eight cases in the first two columns of the third panel of Table 7 (interaction terms) while the other five cases are not significant.

4. This particular result holds only for Money Worries, not for Debt.

\section{References}

Aittomäki A, Martikainen P, Laaksonen M, et al. (2010) The associations of household wealth and income with self-rated health - A study on economic advantage in middle-aged Finnish men and women. Social Science \& Medicine 71(5): 1018-1026.

Andersén J (2017) What about the employees in entrepreneurial firms? A multi-level analysis of the relationship between entrepreneurial orientation, role ambiguity, and social support. International Small Business Journal 35(8): 969-990.

Annink A, Gorgievski M and Den Dulk L (2016) Financial hardship and well-being: A cross-national comparison among the European self-employed. European Journal of Work and Organizational Psychology 25(5): 645-657.

Ariza-Montes A, Arjona-Fuentes JM, Han H, et al. (2018) Work environment and well-being of different occupational groups in hospitality: Job Demand-Control-Support model. International Journal of Hospitality Management 73: 1-11.

Baron RA, Franklin RJ and Hmieleski KM (2016) Why entrepreneurs often experience low, not high, levels of stress: The joint effects of selection and psychological capital. Journal of Management 42(3): 742-768.

Benach J, Vives A, Amable M, et al. (2014) Precarious employment: Understanding an emerging social determinant of health. Annual Review of Public Health 35: 229-253.

Benz M and Frey BS (2008) The value of doing what you like: Evidence from the self-employed in 23 countries. Journal of Economic Behavior and Organization 68(3-4): 445-455.

Binder M (2018) The Way to Wellbeing: A Multidimensional Strategy for Improving Wellbeing of the SelfEmployed. London: Centre for Research on Self-Employment.

Boegenhold D (2019) Are hybrids the new normal? A labour market perspective on hybrid self-employment. International Review of Entrepreneurship 17(4): 429-448.

Boegenhold D and Fachinger U (2012) How diverse is entrepreneurship? Observations on the social heterogeneity of self-employment in Germany. In: Bonnet J, Dejardin M and Madrid-Guijarro A (eds) The Shift to the Entrepreneurial Society: A Built Economy in Education, Sustainability and Regulation. Cheltenham: Edward Elgar Publishing Limited, pp.227-241.

Boegenhold D and Klinglmair A (2015) Micro-entrepreneurship: Tendency towards precarious work? Empirical findings for Austria. Athens Journal of Business \& Economics 1(2): 107-121.

Boersch-Supan A (2017) Survey of Health, Ageing and Retirement in Europe (SHARE), Wave 6 (release version: 6.0.0. SHARE-ERIC). Available at: http://www.share-project.org/fileadmin/pdf_documentation/ MFRB_SHARE_Wave_6_Panel_innovation/2017-01-17_SHARE-WAVE-6_E-Vers.pdf

Boersch-Supan A, Brandt M, Hunkler C, et al. (2013) Data resource profile: The Survey of Health, Ageing and Retirement in Europe (SHARE). International Journal of Epidemiology 42(4): 992-1001.

Broadway B and Haisken-DeNew JP (2019) Keep calm and consume? Subjective uncertainty and precautionary savings. Journal of Economics and Finance 43(3): 481-505.

Buffel V, Missinne S and Bracke P (2017) The social norm of unemployment in relation to mental health and medical care use: The role of regional unemployment levels and of displaced workers. Work, Employment and Society 31(3): 501-521.

Burke AE (2011) The entrepreneurship enabling role of freelancers - Theory with evidence from the construction industry. International Review of Entrepreneurship 9(3): 131-158.

Carrieri V and Jones AM (2017) The income-health relationship 'beyond the mean': New evidence from biomarkers. Health Economics 26(7): 937-956.

Carter KN, Blakely T, Collings S, et al. (2009) What is the association between wealth and mental health? Journal of Epidemiology and Community Health 63(3): 221-226.

Cieslik J and Dvoulety O (2019) Segmentation of the population of the solo self-employed. International Review of Entrepreneurship 17(3): 281-304. 
Clayton M, Liñares-Zegarra J and Wilson JO (2015) Does debt affect health? Cross country evidence on the debt-health nexus. Social Science \& Medicine 130: 51-58.

Coad A (2014) Death is not a success: Reflections on business exit. International Small Business Journal 32(7): 721-732.

Corner PD, Singh S and Pavlovich K (2017) Entrepreneurial resilience and venture failure. International Small Business Journal 35(6): 687-708.

CRSE (2017) The True Diversity of Self-Employment. London: Centre for Research on Self-Employment.

D'Ambrosio C, Jäntti M and Lepinteur A (2020) Money and happiness: Income, wealth and subjective wellbeing. Social Indicators Research 148(1): 47-66.

Fachinger U and Frankus A (2017) Self-employed people and pension: Is old age poverty the inevitable dark side of an entrepreneurial society? In: Bonnet J, Dejardin M and García-Pérez-de-Lema D (eds) Exploring the Entrepreneurial Society: Institutions, Behaviors and Outcomes. Cheltenham; Northampton, MA: Edward Elgar Publishing Limited, pp.245-256.

Ferrer-i-Carbonell A (2005) Income and well-being: An empirical analysis of the comparison income effect. Journal of Public Economics 89(5): 997-1019.

Halvarsson D, Korpi M and Wennberg K (2018) Entrepreneurship and income inequality. Journal of Economic Behavior and Organization 145: 275-293.

Hatak I and Snellman K (2017) The influence of anticipated regret on business start-up behaviour. International Small Business Journal 35(3): 349-360.

Hessels J, Rietveld CA and Van der Zwan P (2017) Self-employment and work-related stress: The mediating role of job control and job demand. Journal of Business Venturing 32(2): 178-196.

Hessels J, van Stel A, Brouwer P, et al. (2006) Social security arrangements and early-stage entrepreneurial activity. Comparative Labor Law and Policy Journal 28(4): 743-774.

Julià M, Vanroelen C, Bosmans K, et al. (2017) Precarious employment and quality of employment in relation to health and well-being in Europe. International Journal of Health Services 47(3): 389-409.

Karasek RA (1979) Job demands, job decision latitude, and mental strain: Implications for job redesign. Administrative Science Quarterly 24(2): 285-308.

Kauhanen M and Nätti J (2015) Involuntary temporary and part-time work, job quality and well-being at work. Social Indicators Research 120(3): 783-799.

Keese M and Schmitz H (2014) Broke, ill, and obese: Is there an effect of household debt on health? Review of Income and Wealth 60(3): 525-541.

Lamu AN and Olsen JA (2016) The relative importance of health, income and social relations for subjective well-being: An integrative analysis. Social Science \& Medicine 152: 176-185.

Leana CR and Meuris J (2015) Living to work and working to live: Income as a driver of organizational behavior. Academy of Management Annals 9(1): 55-95.

Lewis D, Megicks P and Jones P (2017) Bullying and harassment and work-related stressors: Evidence from British small and medium enterprises. International Small Business Journal 35(1): 116-137.

Linder A, Gerdtham UG, Trygg N, et al. (2020) Inequalities in the economic consequences of depression and anxiety in Europe: A systematic scoping review. European Journal of Public Health 30(4): 767-777.

Loretto W and Vickerstaff S (2015) Gender, age and flexible working in later life. Work, Employment and Society 29(2): 233-249.

Lowe TS (2018) Perceived job and labor market insecurity in the United States: An assessment of workers' attitudes from 2002 to 2014. Work and Occupations 45(3): 313-345.

McKee M and Stuckler D (2020) If the world fails to protect the economy, COVID-19 will damage health not just now but also in the future. Nature Medicine 26(5): 640-642.

Matthews KA and Gallo LC (2011) Psychological perspectives on pathways linking socioeconomic status and physical health. Annual Review of Psychology 62: 501-530.

Mwaura S and Carter S (2015) Does entrepreneurship make you wealthy? Insights from the UK Wealth and Assets Survey. ERC Research Paper No. 25, March. Warwick: Warwick Business School and Aston Business School: Enterprise Research Centre.

Nicolaou N, Lockett A, Ucbasaran D, et al. (2019) Exploring the potential and limits of a neuroscientific approach to entrepreneurship. International Small Business Journal 37(6): 557-580. 
Nikolova M (2019) Switching to self-employment can be good for your health. Journal of Business Venturing 34(4): 664-691.

OECD (2013) Framework for Statistics on the Distribution of Household Income, Consumption and Wealth (OECD Better Life Initiative). Paris: OECD Publishing.

Perel P, Langenberg C, Ferrie J, et al. (2006) Household wealth and the metabolic syndrome in the Whitehall II study. Diabetes Care 29(12): 2694-2700.

Preston SH (1975) The changing relation between mortality and level of economic development. Population Studies 29(2): 231-248.

Román C, Congregado E and Millán JM (2011) Dependent self-employment as a way to evade employment protection legislation. Small Business Economics 37(3): 363-392.

Schmalz MC, Sraer DA and Thesmar D (2017) Housing collateral and entrepreneurship. The Journal of Finance 72(1): 99-132.

Schwandt H (2018) Wealth shocks and health outcomes: Evidence from stock market fluctuations. American Economic Journal 10(4): 349-377.

Selenko E and Batinic B (2011) Beyond debt. A moderator analysis of the relationship between perceived financial strain and mental health. Social Science \& Medicine 73(12): 1725-1732.

Shepherd DA (2003) Learning from business failure: Propositions of grief recovery for the self-employed. Academy of Management Review 28(2): 318-328.

Sorgner A, Fritsch M and Kritikos A (2017) Do entrepreneurs really earn less? Small Business Economics 49(2): 251-272.

Srivastava A, Locke EA and Bartol KM (2001) Money and subjective well-being: It's not the money, it's the motives. Journal of Personality and Social Psychology 80(6): 959-971.

Stephan U (2018) Entrepreneurs' mental health and wellbeing: A review and research agenda. Academy of Management Perspectives 32(3): 290-322.

Tedds LM (2008) Estimating the income reporting function for the self-employed. Empirical Economics 38(3): 669-687.

Theorell T and Karasek RA (1996) Current issues relating to psychosocial job strain and cardiovascular disease research. Journal of Occupational Health Psychology 1(1): 9-26.

Tremblay DG and Genin E (2008) Money, work-life balance and autonomy: Why do IT professionals choose self-employment? Applied Research in Quality of Life 3(3): 161-179.

Ucbasaran D, Shepherd DA, Lockett A, et al. (2013) Life after business failure: The process and consequences of business failure for entrepreneurs. Journal of Management 39(1): 163-202.

Van der Zwan P and Hessels J (2019) Solo self-employment and wellbeing: An overview of the literature and an empirical illustration. International Review of Entrepreneurship 17(2): 169-188.

Van Hal G (2015) The true cost of the economic crisis on psychological well-being: A review. Psychology Research and Behavior Management 8: 17-25.

Van Praag B, Frijters P and Ferrer-i-Carbonell A (2003) The anatomy of subjective well-being. Journal of Economic Behavior and Organization 51(1): 29-49.

Wach D, Stephan U and Gorgievski M (2016) More than money: Developing an integrative multi-factorial measure of entrepreneurial success. International Small Business Journal 34(8): 1098-1121.

Wheatley D (2017) Autonomy in paid work and employee subjective well-being. Work and Occupations 44(3): 296-328.

Wiklund J, Nikolaev B, Shir N, et al. (2019) Entrepreneurship and well-being: Past, present, and future. Journal of Business Venturing 34(4): 579-588.

Wood S, Daniels K and Ogbonnaya C (2020) Use of work-nonwork supports and employee well-being: The mediating roles of job demands, job control, supportive management and work-nonwork conflict. The International Journal of Human Resource Management 31(14): 1793-1824.

Yuen W, Sidhu S, Vassilev G, et al. (2018) Trends in Self-Employment in the UK. UK: Office for National Statistics.

Zou H, Chen X, Lam LWR, et al. (2016) Psychological capital and conflict management in the entrepreneurventure capitalist relationship in China: The entrepreneur perspective. International Small Business Journal 34(4): 446-467. 


\section{Author biographies}

Jenny Berrill is an Associate Professor of Finance at Trinity Business School. Her research interests are in the areas of International Business and Finance, Entrepreneurship and Labour Economics. She has published articles in many journals including Social Science and Medicine, Financial Analysts Journal, International Business Review and Small Business Economics.

Damien Cassells is a Lecturer in Finance with the Technological University Dublin. His research interests include mental health in the labour market and energy economics. He has published in several peer reviewed Journals including Social Science \& Medicine, Energy Policy and Gender, Work \& Organization.

Martha O'Hagan-Luff is an Assistant Professor of Finance at Trinity Business School. Her research interests are in the areas of International Finance, Entrepreneurship and Sustainable Finance. She has published articles in many journals including the International Journal of Finance and Economics, International Review of Financial Analysis, International Business Review and Small Business Economics.

André van Stel is a Senior Research Fellow at Trinity Business School, Trinity College Dublin, Ireland, and a Research Professor at Kozminski University in Warsaw, Poland. His research focuses on several topics within the field of the economics of entrepreneurship. He was named among the top 20 authors publishing in the journal Small Business Economics over the period 1989-2018. His work has been published in various other journals as well. André is Associate Editor of the International Review of Entrepreneurship. 